\title{
Effects of Some Heavy Metals in Different Organs and Some Hepatic Enzymes for European eel (Anguilla anguilla) at Lake Edku
}

\author{
Marwa M. Mazrouh \\ Department of Fisheries, Fish Physiology Laboratory, National Institute of Oceanography and Fisheries, Alex., Egypt
}

\begin{abstract}
The study was designed to determine the concentration of some heavy metals in liver, gills, and muscles and the levels of glutamic oxaloacetic transaminase (GOT), glutamic pyruvic transaminase (GPT) and metalothionein (MT) in liver to estimate the efficacy of using methalothioneine as a biomarker for heavy metal stress. Samples of European eel (Anguilla anguilla) collected from Lake Edku. Both agriculture and domestic effluents enter lake from different drains. Copper, Lead, Zinc and Nickel content were determined by atomic absorption spectrophotometer. The highest concentrations of metals were found in liver and gill tissues more than muscle tissues. Concentrations of $\mathrm{Zn}$ and $\mathrm{Cu}$ were significantly higher in the gills and livers of eels more than the concentration of $\mathrm{Pb}$ and $\mathrm{Ni}$. The higher heavy metal concentrations accumulation in gills > liver > muscles respectively. Three enzyme (GOT), (GPT) and $(M T)$ biomarkers were significant $(P<0.05)$ difference with detected heavy metals. It was concluded that alterations in Anguilla liver enzymes GOT, GPT and MT as well as increased may be a result of the tissue damage and dysfunction induced by the heavy metals and these parameters could be used as a rapid bioindicators for monitoring the impact of heavy metals on aquatic organisms.
\end{abstract}

Keywords: European eel, heavy metal, GOT, GPT, Metalothionine, (MT), liver, gill, muscle, Lake Edku

\section{Introduction}

Heavy metals have drastic environmental impact on all organisms. Heavy metal pollution is one of the most serious problems facing people who eating sea foods and affects their physiological state. In Egypt, most of lakes receiving agriculture drainage water mixed with industrial, herbicides and the phosphate fertilizers which are considered as the main source of heavy metals in the environment[1]. The contamination of waters with a wide range of pollutants has become a matter of concern over the last few decades [2,3] .Studies carried out on fish have shown that heavy metals may have toxic effects, altering physiological activities and biochemical parameters both in tissues and in blood of fish $[4,5, \& 6]$. Aquatic organisms such as fish and shell fish accumulate metals to concentrations many times higher than present in water or sediment [7] they can take up metals concentrated at different levels in their different body organs [8] also certain environmental conditions such as salinity, $\mathrm{pH}$, water accumulation in the living organisms up to toxic concentrations and cause ecological damage [9]. The essential metals also become toxic at high concentrations and the toxic effects of heavy metals have been reviewed, including bioaccumulation[10,11\&12]. Lake Edku is a shallow lagoon situated on the western margin of the Nile delta. It is smallest in area comparing with Manzalah or Borollus lakes; it is connected to the Mediterranean through the lake-sea connection Bughaz El- Meadia. The lake can be divided into three ill-defined basins; eastern, central and western. It receives agricultural drain water at its eastern section where two main land drains pour their water through hydraulic pumps. Berzik and Edku-Bousily drains supply water to the lake. The European eel (Anguilla anguilla L.) is a catadromic fish species with its spawning grounds thousands of kilometers away in the ocean, possibly the Sargasso Sea. Young eels entered lake in elvers phase.

Heavy metals may affect the aquatic organisms at the cellular level and possibly change some genes regulation. Measuring heavy metals in aquatic organisms may be a bioindicator of their impact on organism and ecosystem health[13], but a true evaluation of the damage inflected by heavy metals should come from comprehensive biomarker studies. Essential metals, such as copper $(\mathrm{Cu})$ and zinc $(\mathrm{Zn})$, have normal physiological regulatory functions [14], but may also bioaccumulate and reach toxic levels [15].Glutamic oxaloacetic (GOT) and glutamic pyruvic (GPT) transaminases are among many enzymes that play a vital role in protein and carbohydrate metabolism and they are commonly used as biomarkers of environmental pollution and act as an indicator for tissue damage [16,17]. Metallothionein was described by Bouquegneau et al.[18] in European eel. Mts are low molecular weight, cysteine-rich (20-30\%) metalbinding proteins, whose neosynthesis represents a specific response of the organisms to pollution by heavy metals such as $\mathrm{Cu}, \mathrm{Zn}, \mathrm{Cd}$ and $\mathrm{Hg}$. In particular,the metal-binding protein metallothionein (MT) is important for the intracellular binding and regulation of essential and nonessential metals [19].The binding of toxic metals to MT represents a sequester function associated with the cellular protection against metal toxicity[20]. The studies on MT in fish species have consisted basically of the description of the protein and the relation of metallothionein with tolerance to metals, and quantification of MT, either under experimental or under environmental pollution conditions [21-24]. The expression level of metallothionein gene in fish has been used as a biomarker for water pollution with heavy metals $[25,26]$.Quantification of fish metallothionein transcript levels in absolute units has been presented by Evans et al.[27]. It also, considered as early warning for degradation of environmental quality and specific measures of the toxic, carcinogenic and mutagenic compounds in the biological materials [28].The aim of work is to determine the levels of some heavy metals $(\mathrm{Cu}, \mathrm{Pb}, \mathrm{Zn}$, and Ni) in liver, gills and muscles of Anguilla anguilla and GOT, GPT and MT concentrations in liver to assess the efficacy of using metalothionein as a biomarker for heavy 


\section{International Journal of Science and Research (IJSR) \\ ISSN (Online): 2319-7064}

Index Copernicus Value (2013): 6.14 | Impact Factor (2014): 5.611

metal stress.

\section{Materials and Methods}

A total of thirty (n"30) fresh European eels Anguilla anguilla were obtained from local fishermen during the period from June 2010 to March 2011 from Lake Edku (Fig.1). Lake Edku lies in the north of the Nile Delta, west of the Rosetta branch between longitudes $30^{\circ} 8^{\prime} 30^{\prime \prime}$ and $30^{\circ} 23^{\prime} \mathrm{E}$ and Latitudes $31^{\circ} 10^{\prime}$ and $31^{\circ} 018^{\prime} \mathrm{N}$. The lake is connected to the adjacent Abu Qir Bay through Boughaz El Maadiya. Lake receives huge inputs of terrigenous and anthropogenic nutrients discharge, sewage and agricultural runoff via three main drains, Edku, ElBoseily and Barzik situated at its eastern margins drains.

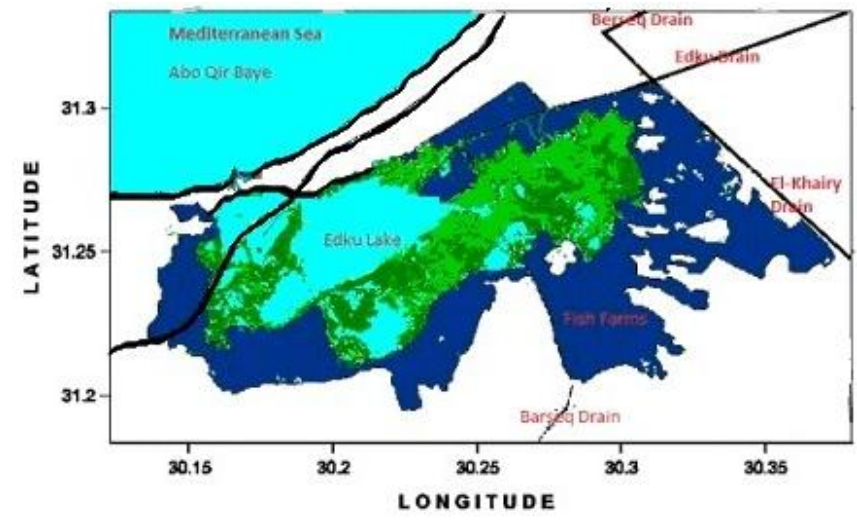

Figure 1: Map of Lake Edku

Samples were kept on ice during transport to physiology laboratory at NIOF, Alexandria. The total average length and weight were $32.4 \mathrm{~cm}$ and $377.9 \mathrm{~g}$ respectively. Heavy metal concentrations were estimated in liver, gills and muscles. These organs were collected and kept frozen at$80^{\circ} \mathrm{c}$ until analysis. One gram of each prepared samples were homogenized and digested in separate Teflon cup using $2 \mathrm{ml}$ of $\mathrm{HNO}_{3}$ and $1 \mathrm{ml}$ of $\mathrm{HClO}_{4}$. Teflon was kept at $100^{\circ} \mathrm{c}$ on hot plate until all materials dissolved and dried. Concentrations of heavy metals were measured using Atomic Absorption Spectrophotometer (Perkin- Elmer) 2280 and values were recorded in $\mu \mathrm{g} \mathrm{g} \mathrm{g}^{-1}$ dry weight. Glutamic oxaloacetic (GOT) and glutamic pyruvic (GPT) transaminases were estimated according to the method of Wooten et al. [29]. After removal of liver, excess water adhering to the tissues were removed by using Whattman filter paper. $100 \mathrm{mg}$ of liver tissue homogenate were prepared in ice-cold glass distilled water with the aid of a chilled all glass homogenizer. The homogenates were centrifuged at $5000 \mathrm{xg}$ for $10 \mathrm{~min}$ and the clear supernatant was used as the enzyme source for enzyme analysis. The results were expressed as $\mu \mathrm{g} / \mathrm{g}^{-1}$ protein. Metallothionein determination was analyzed using a modification of the method described by Viarengo et al.[30]. Tissues were homogenized in a buffer solution of $0.15 \mathrm{M}$ sucrose, $20 \mathrm{mM}$ Tris-HCL ( $\mathrm{pH}$ 8.6), and antiproteolitic agents. The homogenate was then centrifuged at $30000 \mathrm{xg}$ for $20 \mathrm{~min}$ at$4^{\circ} \mathrm{c}$. The supernatant of that sample was purified with 1.05 $\mathrm{ml}$ cold ethanol and $80 \mu \mathrm{l}$ chloroform and centrifuged for 10 minutes at $6000 \mathrm{xg}$ at $-4^{\circ} \mathrm{c}$. The homogenate was then centrifuged at $3000 \mathrm{xg}$ for $20 \mathrm{~min}$ at $-4^{\circ} \mathrm{c}$. The $1 \mathrm{~mL}$ of supernatant was then treated with absolute cold ethanol
$(1.05 \mathrm{~mL})$ and $80 \mu \mathrm{l}$ of chloroform ethanol/chloroform and centrifuged at $6000 \mathrm{xg}$ for $10 \mathrm{~min}$ at $-4^{\circ} \mathrm{c}$. The sample was maintained and allowed the proteins to denature for one hour at $-20^{\circ} \mathrm{c}$ and centrifuged for 10 minutes at $6000 \mathrm{xg}$ at $-4^{\circ} \mathrm{c}$ and the pellet saved. Then discarded the supernatant and added 1 $\mathrm{ml}$ of the previously described buffer solution, $6 \mathrm{ml}$ cold ethanol and $80 \mu \mathrm{l}$ chloroform and centrifuged for 10 minutes at $6000 \mathrm{xg}$ at $-4^{\circ} \mathrm{c}$ and dried under a nitrogen gas stream. A total of $150 \mu \mathrm{l}$ of $1 \mathrm{~N} \mathrm{HCl}$ containing 4mM EDTA was added to the sample. The concentration of $\mathrm{Mt}$ in the extract was quantified spectrophotometrically utilizing the Ellman's SH reagent. Results were compared to a GSH calibration curve.

\section{Statistical Analysis:}

Statistical Analysis of data was carried out using SPSS Inc. version (16) statistical package. One-way analysis of variance (ANOVA) and Duncan multiple range were used to assess whether metal concentrations varied as significantly among tissues. Correlation coefficients between the metals and Mt were computed. Data were expressed as means and standard deviation $(\mathrm{M} \pm \mathrm{SD})$ and the significance level was set at $\mathrm{P}<0.05$.

\section{Results and Discussion}

The heavy metals contamination is one of the vital factors for decline of water quality that has an obvious impact on fish diversity. Consumption of fish from the contaminated site poses a higher health risk to human. The present study focused on the accumulation of heavy metals in A. anguilla and showed differences in heavy metals accumulation in the different tissues. The mean concentrations $( \pm \mathrm{SD})$ of copper, lead, zinc and nickel in liver, gills and muscles of Anguilla anguilla are presented in Table (1). Data showed that there is a significant difference $(\mathrm{P}<0.05)$ between heavy metals among the studies organs. The result shows that $\mathrm{Zn}$ has the highest values in liver and gills $(21.80 \pm 2.70$ and $\left.22.47 \pm 1.39 \mu \mathrm{g} / \mathrm{g}^{-1}\right)$ respectively while $\mathrm{Pb}$ concentration has the lowest values $\left(1.20 \pm 0.22 \mu \mathrm{g} / \mathrm{g}^{-1}\right)$ found in muscles. $\mathrm{Zn}$ was the most abundant of all the metals considered. The $\mathrm{Cu}$ concentrations are significantly higher in gills than liver $\left(11.04 \pm 1.32 \mu \mathrm{g} / \mathrm{g}^{-1}\right.$ and $\left.8.84 \pm 1.53 \mu \mathrm{g} / \mathrm{g}^{-1}\right)$ respectively while the concentration of $\mathrm{Cu}$ is less in muscles $\left(4.31 \pm 0.48 \mu \mathrm{g} / \mathrm{g}^{-1}\right)$. The Ni concentrations are significantly higher in gills than liver $6.65 \pm 0.58 \mu \mathrm{g} / \mathrm{g}^{-1}$ and $5.97 \pm 1.15 \mu \mathrm{g} / \mathrm{g}^{-1}$ respectively; these results are coincided with Bülent et al.[31].The levels of metals accumulate mainly in liver and gills. The trend of accumulation of $\mathrm{Zn}>\mathrm{Cu}>\mathrm{Ni}>\mathrm{Pb}$ were higher in gills $>$ liver $>$ muscles respectively. These results are in accordance with Camusso et al. [32] who reported that zinc accumulated mostly in the gills of Rainbow trout and Ishaq et al. [33] who indicated that Tilapia zilli gills contained the highest concentration $(52.2 \%)$ of all the detected heavy metals and the muscle appeared the least concentration (21.5\%).While other scientists found the highest zinc levels in the kidney, skin and in liver respectively [34-37]. The reason for high metal concentrations in the gills could be due to the metal complexing with the mucus that is impossible to remove completely from the lamellae before analysis[38] and also due to the gill is the primary site for uptake in fish $[39,40]$. 


\section{International Journal of Science and Research (IJSR) \\ ISSN (Online): 2319-7064}

Index Copernicus Value (2013): 6.14 | Impact Factor (2014): 5.611

Table 1: Mean concentrations $\left(\mu \mathrm{g} / \mathrm{g}^{-1}\right)$ with standard deviations and values of metals in liver, gills and muscles of Anguilla anguilla in Lake Edku

\begin{tabular}{|c|c|c|c|c|}
\hline Metals & $\mathrm{Cu}$ & $\mathrm{Pb}$ & $\mathrm{Zn}$ & $\mathrm{Ni}$ \\
\hline Liver & $8.84 \pm 1.53$ & $2.27 \pm 0.39$ & $21.8 \pm 2.70^{*}$ & $5.97 \pm 1.15$ \\
\hline Gill & $11.04 \pm 1.32$ & $2.83 \pm 0.55$ & $22.47 \pm 1.39^{*}$ & $6.65 \pm 0.58$ \\
\hline Muscle & $4.31 \pm 0.48^{* *}$ & $1.20 \pm 0.22$ & $17.84 \pm 1.18$ & $4.8 \pm 0.48^{* *}$ \\
\hline
\end{tabular}

Mean values are significantly different at $(\mathrm{P}<0.05) *$ superscripts are not significantly different $(\mathrm{P}>0.05)$

Liver and gills are metabolically active tissues and accumulate heavy metals of higher levels than muscles as it has been observed in this present study and in many experimental and field studies[41,42]. The levels of heavy metals in fish absorption through food depend upon many factors like the duration of exposure of fish to contaminants in the water, the feeding habits, water chemistry and any contamination of fish during handling and processing, and fish sex, weight, season [43].Those heavy metals accumulate in metabolic organs and stored are detoxificated by producing metallothioneins. In the present study results showed that metal accumulation was higher in gills and liver, whereas it was lower in muscles. The measurement of suitable biomarkers in liver become useful and can give an idea about the health state of fish and more telling than bioindicators because they deal with chemical and physiological changes on the organism level and assess contamination based on a direct measure of change in the organism [44, 45]. Glutamicoxaloacetic transaminase GOT and Glutamic-pyruvic transaminase GPT are two key enzymes considered as a sensitive measure to evaluate hepatocellular damage and some hepatic diseases [46]. Figure (2) shows the elevated values of enzymes in liver of $A$. anguilla compared to control. Changes in the enzymatic activities of aquatic organisms are widely used to demonstrate tissue damage and also diagnosis of fish diseases [17].

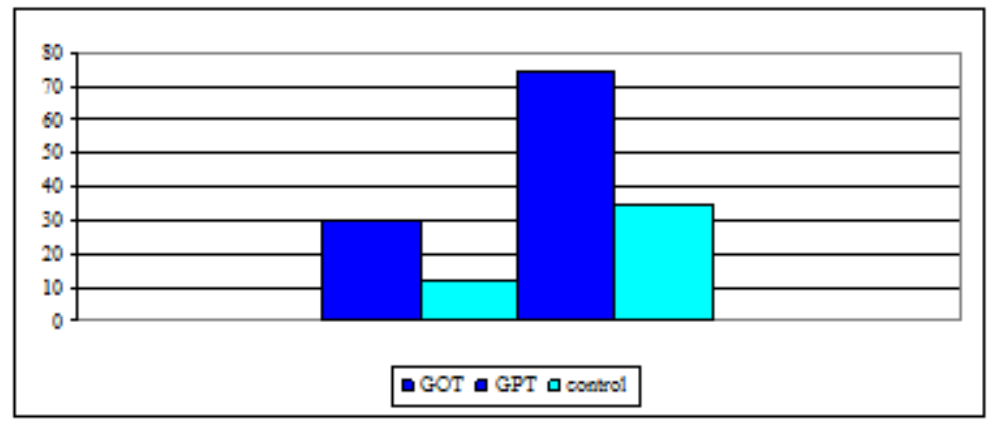

Figure 2: GOT and GPT in Anguilla anguilla from Lake Edku

According to statistical findings there were significantly higher $(\mathrm{P}<0.05)$ differences between $\mathrm{Cu}, \mathrm{Zn}, \mathrm{Ni}, \mathrm{Pb}$ and GOT $\left(29.73 \pm 2.75 \mu \mathrm{g} / \mathrm{g}^{-1}\right)$, GPT $\left(74.77 \pm 8.51 \mu \mathrm{g} / \mathrm{g}^{-1}\right)$ values in Anguilla liver than the controls. The increase was in response to heavy metals and might be attributed to tissue damage, particularly liver; this result was agreement with $[47,48 \& 49]$ in different fish species including $C$. gariepinus. When liver cells are damaged, GOT and GPT levels rise especially early in pollution also the enzyme levels are especially useful in assessing deformed cell and early changes in biliary obstruction and active cirrhosis. Metallothionein (MT) is a low molecular weight protein that binds to heavy metals in aquatic organisms. Metallothionein plays an important role in maintaining intracellular metal homeostasis, eliminating metal toxification and protecting against intracellular oxidative damages and sequesters these metals, thus functioning as a detoxification protein [50]. Moreover, there is a wide range of variation in MT and metal concentrations according to species and organs, depending on age, development status, and other physiological factors[51]. In the present result, the hepatic MT concentrations was $\left(18.20 \pm 3.77 \mu \mathrm{g} / \mathrm{g}^{-1}\right)$ with significant difference $(\mathrm{P}<0.05)$ between heavy metals. Metalothionein is often used to evaluate heavy metal contamination this foundation was coincided with [52] in the accumulation in $\mathrm{Cu}$ and $\mathrm{Zn}$ in liver and gill of eel and increased MT synthesis is associated with increased capacity for binding these metals and protection against metal toxicity. In the case of metal pollution, MT has been suggested to be suitable biochemical indicator this result was coincided with[53,54]. Abundance correlations between different metals and metalothionein levels are presented in table (2). From the table more than one high correlations between the studies metals were observed. $\mathrm{Zn}$ is highly significant relation with MT $(\mathrm{r}=0.628)$ and $\mathrm{Cu}$ correlations are significant $(\mathrm{r}=0.572)$.Correlation between $\mathrm{Ni} \quad \& \mathrm{MT}$ was $(\mathrm{r}=0.398)$.Considered boardline statistically (with a pretty high probability of error $(5 \%)$ these results are in agreement with Langston et al. (2002)[55]. No significant relationships was observed in $\mathrm{Pb}$ in the study however, other significant relations could be also noticed but with less significance.

Table 2: Correlation matrix between the four studies metals and MT in Lake Edku

\begin{tabular}{|c|c|c|c|c|c|}
\hline & $\mathrm{MT}$ & $\mathrm{Cu}$ & $\mathrm{Pb}$ & $\mathrm{Zn}$ & $\mathrm{Ni}$ \\
\hline $\mathrm{MT}$ & 1 & & & & \\
\hline $\mathrm{Cu}$ & $0.573^{*}$ & 1 & & & \\
\hline $\mathrm{Pb}$ & -0.014 & 0.094 & 1 & & \\
\hline $\mathrm{Zn}$ & $0.628^{* *}$ & 0.35 & 0.044 & 1 & \\
\hline $\mathrm{Ni}$ & 0.398 & 0.237 & 0.021 & 0.191 & 1 \\
\hline
\end{tabular}

** Correlations are highly significant at $(\mathrm{P}<.005)-*$ Correlations are significant at $(\mathrm{P}<0.01)$

\section{Conclusion}

The results of this study showed that the concentration of metals in livers and gills were considerably higher than in muscles and the most accumulation of Zinc was in gills. There were significant differences $(\mathrm{P}<0.05)$ between metal studies among liver, gills and muscles and also between GOT, GPT liver enzymes. Significant positive correlations 


\section{International Journal of Science and Research (IJSR) \\ ISSN (Online): 2319-7064}

Index Copernicus Value (2013): 6.14 | Impact Factor (2014): 5.611

were found between metallothionein and $\mathrm{Zn}, \mathrm{Cu}$ and $\mathrm{Ni}$ in liver. No statistically significant differences were found between metallothionein and $\mathrm{Pb}$. Based on the above results, metals bioaccumulation in fish organs did not exceeds the permissible limits set for heavy metals by FAO furthermore the use of enzymatic as biomarker are very important and realistic. Recommendation is the treatment of different wastes before discharging to the natural water sources to protect the fish and the public health from the danger of pollution.

\section{References}

[1] Osman, HAM., Ibrahim, TB., Ali, AT. and Derwa, HIM., 2009.World Applied Sci. J., 6:1569-1575.

[2] Vutukuru. S.S., 2005. Acute effects of Hexavalent chromium on survival, oxygen consumption hematological parameters and some biochemical profiles of the Indian Major carp, Labeo rohita. Int. J. Environ. Res. Public Health.2 (3):456-462

[3] Dirilgen, N., 2001. Accumulation of heavy metals in freshwater organisms: Assessment of toxic interactions. Turk. J. Chem., 25 (3): 173-179

[4] Sani, U., 2011. Determination of some heavy metals concentration in the tissues of Tilapia and Catfishes. Biokemistri 23(2):73-80 online at http://www.bioline.org.br/bk

[5] Basa, S.P. and Rani, A., 2003. Cadmium induced antioxidant defense mechanism in freshwater teleost Oreochromis mossambicus

Eco.Toxicol.Environ.Saf., 56(2):218-221

(Tilapia)

[6] Canli, M., 1995. Natural occurrence of metallothionein like proteins in the hepatopancreas of the Norway lobster Nephrops Norvegicus and effects of $\mathrm{Cd}, \mathrm{Cu}$ and $\mathrm{Zn}$ exposures on levels of the metal bound on metallothionein.Turk. J. Zool., 19: 313-321.

[7] Olaifa FE., Olaifa AK. and Onwude TE.,2004. Lethal and sublethal effects of copper to the African catfish (Clarias gariepnius). Afr. J.Biomed.Res.7:65-67

[8] Khaled A., 2004. Heavy Metal concentrations in certain tissues of Five Commercially Important Fisheries Form Elmed Al-Exandria Egypt. Pp 1-11

[9] Guven k., Ozbay C., Unlu E. and Satar A., 1999. Acute Lethal Toxicity and accumulation of Copper in Gammarus pulex (L.) (Amphipoda).Tur.J.Boil. 23:513-521

[10] Waqar, A., 2006. Levels of selected heavy metals in Tuna fish. Arab. J. Sci. Eng., 31 (1A): 89-92

[11] Adami, G.M., Barbieri, P., Fabiani, M., Piselli, S., Predonzani, S. and Reisenhofer, E., 2002. Levels of cadmium and zinc in hepatopancreas of reared Mytilus galloprovincialis from the Gulf of Trieste (Italy).Chemosphere, 48(7):671 677

[12] Rasmussen, A.D. and Anderson, O., 2000. Effects on cadmium exposure on volume regulation in the lugworm, Arenicola marina. Aquat.Toxicol., 48:151164

[13] Krishnakumar, P.K., Casillas, E., and Varanasi, U., 1994. Effect of environmental contaminants on the health of Mytilus edulis from Puget Sound, Washington, USA.I.Cytochemical measures of lysosomal responses in the digestive cells using automatic image analysis. Marine Ecology Progress Series, 106: 249-261.

[14] Hogstrand, C.and Haux, C., 2001. Binding and detoxification of heavy metals in lower vertebrates with reference to metallothionein.Comp. Biochem.Physiol C., 100: 137.

[15] Rietzler, A.C., Fonseca, A.L.and Lopes G.P., 2001.Heavy metals in tributaries of Pampulha reservoir. Minas. Gerais. Braz. J. Biol., 61: 363.

[16] Nemcsok, J., Benedeczky, I., Boross, L., Asztalos, B.and Orban, L., 1981.Sub cellular localization of transaminase enzyme in fishes and their significance in the detection of water pollution. Acta Biol. 27: 9-15

[17] Nemcsok, J. and Boross, L., 1982. Comparative studies on the sensitivity of different fish species to metal pollution. Acta Biol. Hung., 33: 23-27

[18] Bouquegneau, J.M., Gerday,C. and Disteche, A.,1975. Fish mercury binding thionein related to adaptation mechanisms. FEBS , ett. 55,173-177

[19] Kagi, J.R.and Kojima, Y., 1987.Chemistry and biochemistry of metallothionein. Experienta. 52:25-61

[20] Roesijadi, G., 1992. Metallothioneins in metal regulation and toxicity in aquatic animals. Aquatic Toxicol 22: 81-113

[21] Bonwick, G.A., Vas, P., Fielden, P.R. and Gordon, J.M., 1990.Metallothionein-like proteins in the livers of squaloid and carcharhinid sharks.Marine Pollut. Bull., 21(12): 567-570

[22] Anadu, D.I., Chapman, G.A., Curtis, L.R. and Tubb, R.A., 1989. Effect of zinc exposure on subsequent acute tolerance to heavy metals in rainbow trout. Bull. Environ. Contam. Toxicol. 43, 329-336

[23] Weber, D.N., Eisch, S., Spieler, R.E. and Petering, D.H., 1992. Metal redistribution in largemouth bass (Micropterus salmoides) in response to restraintment stress and dietary cadmium: Role of metallothionein and other metal-binding proteins. Comp. Biochem. Physiol. C101(2): 255-262

[24] Hogstrand, C., Lithner, G. and Haux, C., 1991. The importance of metallothionein for the accumulation of copper, zinc, and cadmium in environmentally exposed perch, Perca fluviatilis. Pharm. Toxicol. 68: 492-501

[25] Tom, M., Chen, N., Segev, M., Herut, B. and Rinkevich, B., 2004. Mar. Pollu . Bull.48:705-710

[26] Sturve, J., Berglund, A., Balk, L., Broeg, K., Bohmert, B., Massey, S., Savva, D., Parkkonen, J., Stephensen, E., Koehler, A. and Forlin, L.,2005.Environ.Toxicol Chem 24:1951-1961

[27] Evans, CW., Wilson, DA. and Mills, GN., 2001. Biomarker, 6:7-14

[28] Verlecar, XN., Pereira, N., Desai, SR., Jena, KB. and Snigdha, 2006. Curr Sci; 91(9-10): 1153-1157

[29] Wooten, I.J.P., 1964. Microanalysis in medical biochemistry. J and A Churchill Ltd, London, W.I.

[30] Viarengo, A., Ponzano, E., Dondero, F. and Fabbri, R., 1997. A simple spectrophotometric method for metallothionein evaluation in marine organisms: an application to Mediterranean and Antartic molluscs. Marine Environmental Research 44: 69-84

[31] Bülent, Y., Fevzi Y. and Tuncer O.G., 2015. Heavy metal concentration in European Eel (Anguilla anguilla L., 1758) from Koycegiz-Dalyan Lagoon system. Feresnius Environ. Bull., 24(5):1607-1613

\section{Volume 5 Issue 2, February 2016}




\section{International Journal of Science and Research (IJSR) \\ ISSN (Online): 2319-7064}

Index Copernicus Value (2013): 6.14 | Impact Factor (2014): 5.611

[32] Camusso, M., Vigano, L. and Balestrini, R., 1995. Bioconcentration of trace metals in rainbow trout: a filed study. Ecotox. Environ. Safe. 31: 133-141

[33] Ishaq, S.E., Rufus, S.A. and Annue, P.A., 2011.Bioaccumulation of heavy metals in fish (Tilapia Zilli and Clarias Gariepinus) organs from River benue, North-Central Nigeria. Pak. J. Anal. Environ Chem. 12 (1\&2):25-31

[34] Kroupa, M.and Hartvich, P., 1990. Selected heavy metals in the tissues of fish in the Luznice River Czechoslovacia, Zivocisna vyroba. 35 (10): 937-994

[35] Kovekovdova, L.T. and Simokon, M., 2002. Heavy metals in tissues of commercial fish populating the Amur Gulf of Japan Sea. Biologiya morya (Marine Biology) 28(2): 125-130.

[36] Fevzi Y., 2009. The Comparison of Heavy Metal Concentrations $(\mathrm{Cd}, \mathrm{Cu}, \mathrm{Mn}, \mathrm{Pb}$ and $\mathrm{Zn})$ in Tissues of Three Economically Important Fish (Anguilla anguilla, Mugil cephalus and Oreochromis niloticus) Inhabiting Köycegiz Lake-Mugla (Turkey),Turkish Journal of Science \& Technology 4(1):7-15

[37] Neto, A.F., Passo, D., Costa, J.L., Costa, M.J., Caçador, I., Pereira, M.E., Duarte, A.C., Pacheco, M. and Domingos, I., 2011. Metal concentrations in the liver of the European eel, Anguilla anguilla, in estuaries and coastal lagoons from Portugal. Life and environment, 61 (3): 167-177

[38] Heath, A.G. (1987) Water Pollution and Fish Physiology. CRC Press, Florida

[39] Yousalfzai, A.M. and Shakoori, A.R., 2008. Heavy metal accumulation in the gills of an endangered South Asian fresh water fish as an indicator of aquatic pollution. Pak.J.Zool.40 (6):423-430

[40] Olawusi, O.O., Ayo-Olalusi, C.I. and Adeyemi, T.V., 2014. Bioaccumulation of some trace element ( $\mathrm{Zn}, \mathrm{Fe}$, $\mathrm{Pb}$ and $\mathrm{Cu}$ ) in the gills and tissues of Clarias gariepinus and Oreochromis nilotica in River Ogbese, Ondo State, Nigeria. J. Environ Chem and ecotoxicol. 6(2):13-19

[41] Barhoumi, S., Messaoudi, I., Gagné, F. and Kerkeni, A., 2012. Spatial and seasonal variability of some biomarkers in Salaria basilisca (Pisces: Blennidae): Implication for biomonitoring in Tunisian coasts. Ecological Indicators, 14(1):222- 228

[42] Figueiredo, A., Fontainhas, A., Rocha, E.and ReisHenriques, M.A., 2006. The effect of paraquat on hepatic EROD activity, liver and gonadal histology in males and females of Nile Tilapia, Oreochromis niloticus, exposed at different temperatures. Archives of Environmental Contamination and Toxicology, 51(4): 626- 632

[43] Boadi, N.O., Twumasi, S.K., Badu, M.and Osei, I., 2011. Heavy metal contamination in canned fish marketed in Ghana. American Journal of Scientific and Industrial Research, 2(6): 877-882

[44] Lafontaine, Y., Gagne, F., Blaise, C., Costan, G., Gagnon, P. and Chan, H., 1999: Biomarkers in zebra mussels (Dreissena polymorpha) for the assessment and monitoring of water quality of the St Lawrence River (Canada), Aquatic Toxicology, 50:51-71

[45] Allen, J. and Moore, M., 2004. Environmental prognostics: Is the current use of biomarkers appropriate for environmental risk evaluation? Marine Environmental Research, 58:227-232.

[46] Ibrahim, S.A. and S.A. Mahmoud, 2005. Effect of heavy metals accumulation on enzyme activity and histology in liver of some Nile fish in Egypt.Egy.J. of Aquc. Biol. and Fisheries, 9(1): 203-219.

[47] Palanivelu, V., Vijayavel, K., Balasubramanian, S.E. and Balasubramanian, M.P., 2005. Influence of insecticidal derivative (cartap hydrochloride) from the marine polychaete on certain enzyme systems of the fresh water fish Oreochromis mossambicus. Journal of Environmental Biology/Academy of Environmental Biology, India, 26(2): 191-195.

[48] Mekkawy, I.A.A., Mahmoud, U.M., Wassif, E.T. and Naguib, M., 2011. Effects of cadmium on some haematological and biochemical characteristics of Oreochromis niloticus (Linnaeus, 1758) dietary supplemented with tomato paste and vitamin E. Fish Physiology and Biochemistry, 37(1): 71-84.

[49] Mohanammbal, R., Puvaneswari, S. and Jiyavudeen M., 2015. Effect of lead (II) nitrate on bio enzymological studies in liver tissue of fish Catla catla (Hamilton), Life Science Archives, 1(2): 41- 45

[50] Mason, A. Z. and Jenkins, K. D., 1995. Metal detoxication in aquatic organisms. In Metal Speciation and Bioavailability in Aquatic Systems, (3) ed. A. Tessier and D.R.Turner : 479-608. Chichester: Wiley

[51] Kagi, J.H. and Schaffer, A., 1998.Biochemistry of metallothionein.Biochemistry, 27: 8509-8515

[52] Rainbow, P.S., Wolowicz, M., Fialkowski, W., Smith, B.D. and Sokolowski, A., 2000.Biomonitoring of trace metals in the Gulf of Gdansk, using mussels (Mytilus trossulus) and barnacles (Balanus improvisus). Water Research 34(6): 1823-182

[53] Amiard, J. C., Amiard-Triquet, C., Barka, S., Pellerin, J. and Rainbow, P. S., 2006.Aquat. Toxicol., 76: 160-202.

[54] Marie, S., Helena, M., Kamila, K., Ondrej, Z., David, H., Vojtech, A., Olga, C., Rene, K. and Zdenka, S., 2013. Effect of Metals on Metallothionein Content in Fish from Skalka and Želivka Reservoirs. Int. J. Electrochem. Sci., 8:1650 - 1663

[55] Langstona, W.J., Chesmana, B.S., Burta, G.R., Popeb, N.D. and McEvoyc, J., 2002: Metallothionein in liver of eels Anguilla anguilla from the Thames Estuary: an indicator of environmental quality? Marine Environmental Research, 53:263-293 